\title{
Oscillatory interference in parietal cortex: a mechanism to represent order in working memory
}

\author{
Nicolas W Schuck ${ }^{1 *}$, Neil Burgess ${ }^{2,3}$ \\ From Nineteenth Annual Computational Neuroscience Meeting: CNS*2010 \\ San Antonio, TX, USA. 24-30 July 2010
}

Previous research has indicated that an oscillatory interference mechanism can explain the behaviour of entorhinal grid cells that encode the current location of an animal in continuous space [1]. Here, we show that a similar mechanism can explain the behaviour of rankorder cells in parietal cortex that encode the current position in continuous time. In line with recent neurophysiological [2] and computational [3] work we additionally propose the resulting time code to play a role in working memory for serial order. We developed a model of working memory that assumes an oscillatory interference mechanism encoding the order of items. Our assumptions are in line with single cell recordings from neurons coding for the cumulated number of encountered events [4]. The internal behaviour of the model is consistent with behaviour of neurons coding the rank order of items [5]. Our model corresponds to the temporal context signal posited by models of immediate serial recall such as [6], and can account for a number of detailed effects in working memory for serial order, and makes some novel, testable predictions.

Specifically, our model shows that an activation pattern resulting from interfering dendritic and somatic membrane potential oscillations (MPO) of different frequencies resembles the activation profiles of parietal rank-order sensitive cells. We modeled an increasing dendritic input that leads to a MPO frequency increase. The input is delivered by parietal 'accumulator neurons' whose firing rate increases with the number of presented items [4]. Hence, our model illuminates a possible relation between accumulator neurons and labeled-line rank order cells that has long been debated

\footnotetext{
* Correspondence: nicolas.schuck@hu-berlin.de

'Department of Psychology, Humboldt University, 10099 Berlin, Germany
}

[7]. In this respect, we provide an alternative to other models on this topic [8]. Modeling an ensemble of neurons with random phase-shifts between dendritic and somatic MPOs leads to a continuous time-varying state of the neuron ensemble that can be used as a neuronal code for time or order. This code has a number of features in common with intraparietal rank-order cells [5]: The similarity-function changes its shape over time such that early in time two states are more distinct than later in time (with identical time-lag in both cases), and similarity to a specific time is a slightly left-skewed tuning curve. These properties are important as they can explain findings from numerical cognition [5] and working memory [3]. Moreover, we extended the model to simulate working memory tasks (compare [3]). There, our model predicts specific effects of inter-item-intervals on correct recall and intrusions.

\section{Acknowledgements}

This work was supported by a Erasmus SMP Scholarship and the Medical Research Council UK.

\section{Author details}

'Department of Psychology, Humboldt University, 10099 Berlin, Germany. ${ }^{2}$ UCL Institute of Cognitive Neuroscience, University College London, WC1N 3AR, UK. ${ }^{3}$ UCL Institute of Neurology, University College London, WC1N 3BG, UK.

Published: 20 July 2010

\section{References}

1. Burgess N, Barry C, O'Keefe J: An oscillatory interference model of grid cell firing. Hippocampus 2007, 17(9):801-812.

2. Marshuetz C, Reuter-Lorenz P, Smith EE, Jonides J, Noll DC: Working memory for order and the parietal cortex: an event-related functional magnetic resonance imaging study. Neuroscience 2006, 139(1):311-316.

3. Botvinick $M$, Watanabe J: From numerosity to ordinal rank: a gain-field model of serial order representation in cortical working memory. J Neurosci 2007, 27(32):8636-8642. 
4. Roitman JD, Brannon EM, Platt ML: Monotonic coding of numerosity in macaque lateral intraparietal area. PLoS Biol 2007, 5(8):e208.

5. Nieder A, Diester I, Tudusciuc O: Temporal and spatial enumeration processes in the primate parietal cortex. Science 2006, 313(5792):1431-1435.

6. Burgess $N$, Hitch GJ: A revised model of short-term memory and longterm learning of verbal sequences. J Mem \& Lang 2006, 55:627-652.

7. Opstal FV: Labeled-line coding and summation coding of numerosities in prefrontal and parietal cortex. J Neurosci 2007, 27(36):9535-9536.

8. Verguts T, Fias W: Representation of number in animals and humans: A neural model. J Cogn Neurosci 2004, 16(9):1493-1504.

doi:10.1186/1471-2202-11-S1-P173

Cite this article as: Schuck and Burgess: Oscillatory interference in parietal cortex: a mechanism to represent order in working memory. BMC Neuroscience 2010 11(Suppl 1):P173.

\section{Submit your next manuscript to BioMed Central} and take full advantage of:

- Convenient online submission

- Thorough peer review

- No space constraints or color figure charges

- Immediate publication on acceptance

- Inclusion in PubMed, CAS, Scopus and Google Scholar

- Research which is freely available for redistribution

Submit your manuscript at www.biomedcentral.com/submit 